\title{
IMPLEMENTASI KURIKULUM 2013 MATA PELAJARAN BAHASA INDONESIA DI KABUPATEN KLATEN
}

\author{
Wisnu Nugroho Aji dan Ngumarno \\ PBSI FKIP Universitas Widya Dharma Klaten \\ PBSI FKIP Universitas Widya Dharma Klaten \\ wisnugroaji@unwidha.ac.id
}

\begin{abstract}
The aim purpose of this research is to describe the implementation of curriculum 2013 in Indonesian language subjects at Klaten Regency. The implementation based on the implementation of learning, difficulties of the implementation and how about the solution to overcome these obstacles. This research is a case study study focusing on the implementation of the 2013 curriculum in Indonesian subjects. This research takes place in SMA Negeri 3 Klaten by taking sample class XII. The data sources used for the excavation and data collection are 1) Events, teaching and learning activities using the Curriculum 2013; 2) Informants, involving teachers and students; And 3) Documents, files and archives related to the implementation of the 2013 curriculum. The results of research indicate that there are still many obstacles problems in implementing the 2013 curriculum in several aspects, such as: limited time of learning implementation, facilities and prasarna, and assessment / evaluation
\end{abstract}

Keywords: Curriculum 2013, Indonesian teaching and learning

\begin{abstract}
Abstrak. Tujuan Penelitian ini adalah untuk mengetahui dan mendeskripsikan implementasi kurikulum 2013 pada mata pelajaran bahasa Indonesia di Kabupaten Klaten. Bentuk implementasi tersebut diuraikan berdasarkan pelaksanaan pembelajaran, kendala dalam pelaksanaan serta tindakan yang dilakukan untuk mengatasi kendala tersebut. Penelitian ini merupakan penelitian studi kasus dengan berfokus pada implementasi kurikulum 2013 pada mata pelajaran bahasa Indonesia. Tempat penelitian dilakukan di SMA Negeri 3 Klaten dengan mengambil sampel kelas XII. Sumber data yang digunakan untuk penggalian dan pengumpulan data adalah 1) Peristiwa, kegiatan pengajaran dan pembelajaran dengan menggunakan Kurikulum 2013; 2) Informan, melibatkan guru dan siswa; dan 3) Dokumen, berkas dan arsip terkait pelaksanaan kurikulum 2013. Hasil penelitian menunjukkan masih banyak kendala dalam mengimplementasikan kurikulum 2013 pada beberapa aspek, antara lain: keterbatasan waktu pelaksanaan pembelajaran, sarana dan prasarna, dan penilaian/evaluasi
\end{abstract}

Kata kunci: Kurikulum 2013, Pengajaran bahasa Indonesia

\section{Pendahuluan}

Persoalan pendidikan yang masih mengganjal dalam sistem pendidikan di Indonesia adalah pergantian kurikulum. Kurikulum merupakan bidang yang sulit untuk dipahami, tetapi sangat terbuka untuk didiskusikan. Revitalisasi dan penekanan karakter dalam Kurikulum 2013 diharapkan dapat menyiapkan generasi Indonesia yang berkualitas sehingga masyarakat dan bangsa 
Indonesia dapat menghadapi berbagai masalah dan tantangan yang semakin rumit dan kompleks di era globalisasi. Kurikulum 2013 merupakan langkah positif pemerintah (Mendikbud) merevitalisasi pendidikan karakter dalam seluruh jenis dan jenjang pendidikan. Kurikulum 2013 lebih menekankan pada pendidikan karakter. Pengembangan Kurikulum 2013 merupakan kurikulum yang berbasis karakter dan kompetensi, dengan demikian dapat menghasilkan generasi yang betul-betul produktif, kreatif, inovatif, dan berkarakter.

Implementasi Kurikulum 2013 dilaksanakan terbatas dan bertahap (sebagai uji coba) mulai tahun ajaran 2013 (Juli) pada jenjang pendidikan dasar dan menengah. Untuk sekolah dasar, dimulai di kelas I dan IV, kelas VII untuk SMP, dan kelas IX untuk jenjang SMA. Pada awalnya, Kurikulum 2013 akan diimplementasikan pada $30 \%$ SD, dan $100 \%$ SMP, SMA dan SMK sehingga tahun 2016 semua sekolah sudah mengimplementasikan. Namun, untuk tahun ajaran 2013 baru beberapa sekolah yang mengimplementasikan sebagai uji coba. Sekolah tersebut adalah beberapa sekolah unggulan yang dipandang siap mengimplementasikan Kurikulum 2013, seperti Rintisan Sekolah Bertaraf Internasional (RSBI).

DalampenelitianBintari

diketahuiimplementasi sudah dilakukan di beberapa sekolah, namun guru masih mengalami beberapa kendala dalam pelaksanaan karena terdapat beberapa perbedaan dengan kurikulum sebelumnya. Guru umumnya beranggapan bahwa pengembangan kurikulum bukan merupakan tugas guru. Hal ini terjadi karena adanya hilang konsep terhadap pemahaman kurikulum. Kurang pemahaman terhadap kurikulum menyebabkan implementasi sebuah kurikulum berjalan tidak ideal. Guru terkadang beranggapan bahwa tugas guru hanya mengajarkan materi di kelas. Selain itu, juga disebabkan oleh pemahaman guru yang masih kurang terhadap Kurikulum 2013. Guru merupakan salah satu kunci sukses dan agen pengembangan implementasi Kurikulum 2013. Guru berada dalam keadaan strategis, dalam artian yang mengetahui kondisi di lapangan. Guru adalah pihak yang mengetahui tingkat perkembangan peserta didik, perbedaan daya serap, suasana pembelajaran, sarana dan sumber belajar yang tersedia. Guru diberikan keleluasaan mengelola pembelajaran sesuai kreativitas yang dimiliki. Sosialisasi dan pelatihan Kurikulum 2013 dilakukan untuk mempersiapkan guru dalam mendukung implementasi.

Dari beberapa hal di atas, dapat disimpulkan kesiapan guru dalam mendukung keterlaksanaan Kurikulum 2013. Selain itu, dapat mengetahui kesulitan atau hambatan yang dirasakan oleh guru dalam mengimplementasikan Kurikulum 2013. Tanggapan tersebut dapat menjadi masukan kepada pemerintah untuk bersama-sama memperbaiki atau menemukan solusi untuk menyempurnakan Kurikulum 2013 serta melihat sejauh mana sosialisasi membantu guru memahami kurikulum baru. Hal tersebut dihara pkan dapat menjadi renungan sekaligus evaluasi kelayakan implementasi Kurikulum 2013 pendidikan Indonesia.

\section{Metode Penelitian}

Penelitian ini merupakan jenis penelitian studi kasus. Penelitian ini merupakan pengujian secara rinci terhadap satu pristiwa, yakni implementasi kurikulum 2013 pada mata pelajaran bahasa Indonesia. Tempat penelitian dilakukan di SMA Negeri 3 Klaten dengan mengambil sampel kelas XII. Penelitian ini dilaksanakan pada semester genap tahun ajaran 2015/2016. Penelitian ini berlangsung selama 4 bulan, yaitu pada bulan April 2016 sampai dengan Juli 2016.

Sumber data yang digunakan untuk penggalian dan pengumpulan data adalah 1) Peristiwa, kegiatan pengajaran dan pembelajaran dengan menggunakan Kurikulum 2013; 2) Informan, melibatkan guru dan siswa; dan 3) Dokumen, berkas dan arsip terkait pelaksanaan kurikulum 2013. 
Teknik pengumpulan data yang digunakan adalah 1) Observasi untuk mengambil data berupa peristiwa; 2) Wawancara mendalam untuk mengambil data dari informan; dan 3) Analisis dokumen untuk mengambil data berupa dokumen.

Teknik Analisis data yang digunakan adalah menggunakan analisis mengalir Milles dan Huberman. Proses analisis tersebut dapat dilakukan melalui tiga langkah, sebagai berikut: 1) Reduksi data; 2)Penyajian data; dan 3)Penarikan Kesimpulan.

\section{Hasil Penelitian Dan PemBahasan}

\section{A. Implementasi Kurikulum 2013}

Di Kabupeten Klaten ada enam sekolah menengah negeri yang mengimplementasikan Kurikulum 2013 sejak tahun pertama (2013/2014). Sekolah-sekolah tersebut merupakan pionir atau sekolah sasaran sebagai uji coba implementasi Kurikulum 2013. Dari data wawancara, diketahui secara pasti bahwa keenam sekolah tersebut memang sebagai sekolah sasaran Kurikulum 2013. Pada tahun pertama implementasi dilaksanakan pada kelas X, kemudian implementasi tahun kedua mulain dilaksanakan pada kelas X dan XI setiap sekolah.

Guru-guru yang mengimlementasikan pada awalnya melewati diklat terlebih dahulu. Implementasi Kurikulum 2013 pada tahun pertama dilaksanakan hanya pada kelas X, maka diklat difokuskan pada guru yang mengajar kelas X. Setelah guru kelas X mendapat diklat, kemudian diklat diberikan kepada guru lain secara bergantian. Beberapa guru ketika diwawancara mengatakan bahwa diklat kurang membantu. Diklat yang didapat tidak memberikan gambaran secara jelas dan rinci mengenai implementasi Kurikulum 2013. Beberapa guru merasa pengimplementasian Kurikulum 2013 sangat dipaksakan. Pemahaman guru mengenai Kurikulum 2013 memang sangat penting. Kurikulum 2013 dalam proses pembelajaran diterapkan oleh guru, jika pemahaman mengenai Kurikulum 2013 belum baik, bagaimana guru dapat mengimplementasikan dengan baik. Implementasi Kurikulum 2013 di Kabupaten Klaten dapat diketahui dari komponen sebagai berikut.

\section{RPP (Rencana Pelaksanaan Pembelajaran)}

Menurut David (2010) di jelaskan salah satu komponen terpenting dalam pelaksanaan pembelajaraan adalah desain. Desain pembelajaran yang dimaksud disini adalah Rancangan Pembelajaran. Berdasarkan hasil wawancara guru mengatakan bahwa RPP 2013 mengalami perubahan jika dibandingkan dengan RPP kurikulum sebelumnya. Akan tetapi, konten dan garis besar dari RPP antara Kurikulum 2013 dengan KTSP tetap sama. Dari hasil wawancara, guru menuturkan bahwa guru menyiapkan RPP sendiri yang diturunkan berdasarkan silabus. Adapun untuk bentuk atau format RPP, beberapa guru menggunakan format yang disetujui forum MGMP Bahasa Indonesia Klaten dan beberapa guru menggunakan format dari dinas. Namun, antara format MGMP dengan format dinas memunyai ketidakseragaman. Hal tersebut menimbulkan kebingungan bagi guru. Guru-guru menyatakan sebaiknya ada keseragaman antara MGMP dan dinas, sehingga guru menggunakan satu format RPP saja.

\section{Pendekatan Saintifik}

Berdasarkan wawancara, guru mengatakan bahwa sebenarnya pendekatan saintifik sudah dilaksanakan sejak KTSP. Hanya saja pada kurikulum sebelumnya tidak dikenal dengan istilah pendekatan saintifik. Kegiatan mengamati, menanya, menalar, mengasosiasikan, dan mengomunikasikan sebenarnya sudah diterapkan. Hal tersebut sesuai dengan penjelasan dalam Materi Pelatihan Guru Implementasi Kurikulum 2013 dalam Modul Pelatihan Implementasi Kurikulum 2013 (Kemendikbud, 2013:194207) meskipun dalam pelaksanaannya belum terorganisasi.

Guru berpendapat jika langkah pendekatan saintifik belum dapat dilaksanakan 
semua tidak menjadi masalah.Bagi guru yang terpenting adalah tujuan pembelajaran tercapai dan materi dapat dipahami dengan baik oleh peserta didik. Keaktifan peserta didik dalam proses pembelajaran belum menyeluruh. Belum semua peserta didik aktif dalam pembelajaran. Salah satu guru mengatakan bahwa peserta didik aktif, karena memang dituntut untuk aktif. Peserta didik harus dapat mengimbangi dan menyesuaikan proses pembelajaran sesuai dengan Kurikulum 2013.

\section{Metode Pembelajaran}

Guru juga menggunakan metode lain yang dirasa cocok dan tepat pada peserta didik untuk materi tertentu. Kurikulum 2013 juga menganjurkan pembelajaran tidak hanya dilaksanakan di dalam kelas, pembelajaran bisa dila kukan di luar kelas. Berdasarkan hal tersebut, beberapa guru mengungkapkan sudah melaksanakan pembelajaran di luar kelas. Namun, sebagian besar guru mengungkapkan untuk sementara waktu masih melaksanakan pembelajaran di dalam kelas. Guru yang sudah melaksanakan pembelajaran di luar kelas berpendapat bahwa hal tersebut dilakukan untuk mengatasi rasa bosan peserta didik jika melakukan pembelajaran di dalam kelas secara terusmenerus.

\section{Media Pembelajaran}

Berdasarkan hasil wawancara, media yang paling sering digunakan guru adalah LCD proyektor, audio-visual, dan teks pendukung. Semua sekolah memang sudah menyediakan LCD di tiap kelas. Media tambahan lain juga digunakan guru, seperti buku, koran, majalah, alat peraga, lingkungan sekitar, ataupun internet. Seiring perkembangan zaman, internet merupakan fasilitas yang sangat diperlukan. Pemilihan media tersebut dilakukan guru menyesuaikan materi yang diajarkan agar peserta didik dapat memahami materi dengan baik.

\section{Sumber Belajar}

Dari hasil wawancara juga diketahui bahwa buku pedoman tersebut masih perlu direvisi. Hal tersebut disebabkan karena masih ditemukan kesalahan baik konten maupun penulisan dalam buku. Pada implementasi Kurikulum 2013 tahun ke-2, buku pegangan tersebut sudah direvisi. Guru mengatakan hasil revisi sudah cukup baik, meskipun masih terjadi banyak kesalahan tulis.

\section{Penilaian}

Penilaian merupakan bagian penting dan tak terpisahkan dalam sistem pendidikan saat ini. Peningkatan kualitas pendidikan dapat dilihat dari nilai-nilai yang diperoleh siswa (Iswardah:2007),.Berdasarkan data wawancara, memperoleh data bahwa selama ini implementasi tetap berjalan dan mengalami perbaikan pada tahun kedua. Sekolah yang telah mengimplementasikan Kurikulum 2013 terus membuat perbaikan dalam implementasi yang dirasa kurang pada implementasi tahun pertama. Implementasi Kurikulum 2013 pada tahun pertama, hampir semua penilaian sudah dilaksanakan. Namun, pada tahun kedua baru beberapa yang dilaksanakan, karena baru menginjak semester gasal. Berdasarkan hasil wawancara, guru mengatakan bahwa masih mengupayakan melaksanakan penilaian yang belum dapat dilaksanakan.

\section{B. Kendala Implementasi Kurikulum 2013}

Berikut penjelasan mengenai kendalakendala yang dialami guru mata pelajaran Bahasa Indonesia di SMAN se-Kabupaten Klaten berdasarkan penelitian dalam menerapkan Kurikulum 2013.

\section{Keterbatasan Waktu}

pelaksanaan pembelajaran juga terkendala keterbatasan waktu. Mata pelajaran Bahasa Indonesia dalam satu minggu menjadi 4 jam pelajaran. Di Kabupeten Klaten, ada yang langsung 4 jam dalam satu pertemuan 
dan ada yang dibuat menjadi $2 \times 2$ jam dalam seminggu. Hal ini menyesuaikan keadaan sekolah masing-masing dan menyesuaikan jadwal dengan mata pelajaran lain. Jika dibuat 4 jam langsung pada satu pertemuan, materi bisadisampaikan langsung hingga selesai namun te rkendala peserta didik akan merasa bosan karena terlalu lama. Jika dibuat $2 \times 2$ jam, biasanya pertemuan pertama hanya sampai pada tahap menalar, kemudian sisanya diteruskan pada pertemuan selanjutnya.

\section{Keterbatasan Sarana dan Prasarana}

Dikatan dalam Sagala (2003), bahwa kebermaknaan pembelajaran sangat ditunjang oleh sarana dan prasarana yang melengkapinya. Berdasarkan hasil wawancara, buku siswa pada cetakan pertama masih kurang sempurna dan sangat perlu direvisi. Kekurangan buku siswa tersebut bisa dilihat dari konten bukunya maupun tanda baca atau kesalahan penulisan. Materi di dalam buku tidak urut sesuai dengan silabus dan ada materi yang belum ada. Ketidaksesuaian materi membuat guru harus menyesuaikan antara buku dan silabus serta mele ngkapi materi sendiri. Buku kurang menjelaskan materi, sehingga guru perlu mencarikan tambahan materi agar pengetahuan peserta didik lebih lengkap.

\section{Kendala Penilaian}

Pada semester ketiga implementasi Kurikulum 2013, guru mengatakan bahwa penilaian proyek belum dilaksanakan. Namun, untuk pelaksanaan pada tahun pertama sudah dilaksanakan. Penilaian yang sudah dilaksanakan di keenam sekolah tersebut biasanya adalah penilaian diri, penilaian teman sejawat, penilaian portofolio, penilaian tertulis, jurnal oleh beberapa guru, dan observasi. Sedangkan penilaian lain akan dilaksanakan seiring berjalannya waktu. Kesulitan dalam penilaian yang dirasakan adalah ketika proses pemberian materi, guru juga harus menilai perilaku siswa. Berkaitan dengan hal tersebut guru merasa kurang fokus. Banyaknya jenis penilaian membuat guru merasa bingung menentukan waktu pelaksanaan penilaian. Sementara guru masih memiliki tugas lain yang harus dipenuhi, namun juga harus melaksanakan berbagai jenis penilaian. Hal ini mengakibatkan belum terlaksananya semua penilaian dan berkaitan dengan keterbatasan waktu.

\section{Kendala Keaktivan Peserta Didik dalam Proses Belajar Mengajar}

Berdasarkan wawancara, salah satu guru mengungkapkan bahwa peserta didik di sekolahnya sudah aktif secara keseluruhan. Namun, pada sekolah lainnya keaktivan peserta didik belum merata. Berdasarkan hasil wawancara, ada kelas yang memiliki peserta didik aktif hanya di kelas tertentu. Ada juga hanya ada beberapa anak aktif dalam satu kelas, dan sisanya masih tergolong pasif. Hal ini dipengaruhi oleh perbedaan individu masing-masing peserta didik. Peserta didik yang tergolong pasif adalah peserta didik yang7766pendiam, pemalu atau kurang percaya diri. Peserta didik ini tidak terbiasa berbicara di muka umum.

\section{Upaya Guru dalam Mengatasi Kendala Implementasi Kurikulum 2013}

Berikut pembahasan mengenai upayaupaya yang dilakukan guru mata pelajaran Bahasa Indonesia di SMAN se-Kabupaten Klaten.

\section{Upaya Mengatasi Kendala Keterbatasan Waktu}

Keterbatasan waktu yang dialami guru berupa keterbatasan waktu dalam menyelesaikan administrasi guru, perencanaan pembelajaran, proses pembelajaran, dan penilaian. Upaya yang dilakukan guru untuk mengatasi kendala tersebut adalah: (1) Administrasi merupakan tugas masing-masing guru. Administrasi guru dapat berupa RPP, Program Tahunan, Program Semester, Rubrik Penilaian, Pedoman Penilaian, Analisis, SK/KD, dll. Banyak administrasi guru yang perlu dibuat, guru 
mengatasi dengan menyelesaikan di rumah, (2) Pembuatan RPP juga dilaksanakan di rumah dengan mengorbankan waktu bersama keluarga atau mengurangi waktu istrirahat di rumah. Hal ini dilakukan karena tidak memungkinkan pembuatan RPP dilaksanakan di sekolah, (3) Keterbatasan waktu dalam proses pembelajaran, guru melakukan upaya dengan penugasan atau pengerjaan soal. Satu pertemuan guru mengusahakan pemberian materi selesai dan tujuan pembelajaran tercapai. Jika karena alasan tertentu tujuan belum tercapai, guru akan melanjutkan pada pertemuan selanjutnya, (4) Upaya guru dalam mengatasai keterbatasan waktu dalam penilaian dilakukan dengan melihat kondisi dan situasi yang ada di dalam kelas. Jika tidak memungkin memberikan penilaian secara individu, guru akan melakukan penilaian kelompok yang biasanya berupa penilaian proyek. Upaya yang lain juga ketika tidak waktu terbatas memberikan penilaian di dalam kelas, guru akan memberikan penilaian di luar kelas (observasi atau jurnal).

\section{Upaya Mengatasi Kendala Keterbatasan Sarana dan Prasarana}

Keterbatasan sarana dan prasarana di beberapa sekolah cukup mengganggu proses pembelajaran. Tuntutan kompetensi dasar yang harus menggunakan teknologi dalam pembelajaran tidak disertai dengan ketersediaan sarana dan prasarana penunjangnya. Akibatnya, pe laksanaan pembelajaran terganggu dan penilaian juga tidak dapat dilakukan secara maksimal. Guru mata pelajaran Bahasa Indonesia di SMAN se-Kabupaten Klaten mengatasi kendala keterbatasan sarana dan parasarana dengan melakukan upaya berupa berusaha kreatif memanfaatkan media yang tersedia.

Kelas yang tidak dilengkapi dengan LCD, guru akan membawa LCD pada setiap pembelajaran. Guru akan menggunakan media lain jika tidak memperoleh LCD. Di zaman globalisasi seperti saat ini, internet menjadi sumber belajar yang penting. Sekolah dengan sarana internet kurang bagus, guru akan mengatasi dengan memperbolehkan peserta didik menggunakan handphone untuk keperluan browsing materi. Sementara untuk keterlambatan buku, ada guru yang memberikan hasil print dan ada yang memberikan softfile. Namun, penggunaan softfile dianggap kurang nyaman nyaman dilakukan dalam pembelajaran.

\section{Upaya Mengatasi Kendala Penilaian}

Melalui wawancara diketahui bahwa guru mengalami kesulitan dalam pembuatan rubrik penialaian. Guru mengatasi hal tersebut dengan membahas dan membuat pedoman rubrik penilaian yang kemudian dapat digunakan bersama dalam forum MGMP. Sebelumnya, guru juga membaca berbagai buku mengenai penilaian untuk menambah pengetahuan mengenai penilaian yang perlu dilakukan. Guru mengatasi kendala penilaian dengan upaya membuat rencana dan gambaran yang sesuai dengan keadaan peserta didik.

Banyaknya jenis penilaian dalam Kurikulum 2013 di atasi dengan melakukan penilaian satu persatu dan melihat kondisi penilaian yang memungkinkan dilaksanakan terlebih dahulu. Melalui hasil wawancara, penilaian diri dan teman sejawat dilaksanakan sebelum tes tertulis. Guru mengatasi penilaian portofolio yang sulit dilaksanakan dengan memberikan tugas kepada peserta didik dan dikumpulkan menjadi satu buku tugas. Beberapa sekolah melakukan penilaian proyek dengan penugasan kelompok dan dikerjakan di luar jam pelajaran. Upayaupaya tersebut sudah dilakukan guru secara maksimal guna mengimplementasikan Kurikulum 2013 sesuai dengan harapan dan idealnya. Kendala lain yang belum bisa diatasi, masih dalam proses menemukan upaya dan solusi yang tepat dengan kendala yang dialami. 


\section{Upaya dalam Mengatasi Kendala Keaktivan Peserta Didik dalam Poses Belajar Mengajar}

Guru mengatasi keterbatasan peserta didik dengan memberikan motivasi kepada peserta didik yang masih pasif. Motivasi bertujuan untuk menambah kepercayaan diri peserta didik. Hal tersebut senada dengan hasil penelitian Maryam (2013). Berdasarkan hasil wawancara guru mengatakan perlu memberikan rangsangan-rangsangan atau pancingan kepada peserta didik yang pendiam dan pemalu untuk berani berbicara di depan kelas. Guru juga mengungkapkan memberikan pujian atau memberikan tambahan nilai bagi peserta didik aktif dalam pembelajaran. Guru mengaku bahwa tidak mudah membuat peserta didik tersebut bersedia meng ekspresikan diri di depan kelas. Guru juga melakukan upaya dengan memilih dan menggunakan metode yang tepat. Hasil wawancara diperoleh data bahwa metode yang paling sering digunakan adalah metode diskusi. Metode diskusi dianggap sesuai untuk mengatasi peserta didik yang pasif. Peserta didik diharapkan ikut serta aktif dalam diskusi beserta kelompok, aktif mencari data dan belajar mandiri, dan berani menyampaikan hasil diskusi di depan kelas.

Diskusi kelompok juga dianggap sebagai ruang untuk berekspresi, karena berdiskusi bersama teman bertujuan agar setiap anak tidak merasa canggung. Presentasi digunakan guru sebagai tempat bagi peserta didik untuk mengekspresikan hasil pekerjaan dalam diskusi.

\section{Simpulan}

Berdasarkan hasil penelitian dan pembahasan yang telah d29isampaikan pada bab IV maka dapat disimpulkan bahwa.

1 Guru kelas XII mata pelajaran Bahasa Indonesia SMA Negeri 3 Klaten mengimplementasikan Kurikulum 2013 dalam pembelajaran berupa: a) penyusunan RPP berdasarkan silabus yang disiapkan pemerintah menggunakan format MGMP Bahasa Indonesia
Kabupaten Klaten atau format dinas, b) penggunaan pendekatan saintifik dalam proses pembelajaran, c) penggunaan metode yang sering diterapkan adalah diskusi, tanya jawab, dan penugasan yang terangkum dalam pendekatan saintifik, d) penggunaan media LCD proyektor, audio-visual, dan teks pendukung dalam proses belajar, e) sumber belajar berupa buku wajib dari pemerintah, buku dari penerbit lain sebagai referensi, dan internet, f) penggunaan penilaian sesuai Kurikulum 2013.

2. Tanggapan guru Guru kelas XII mata pelajaran Bahasa Indonesia SMA Negeri 3 Klaten terhadap Kurikulum 2013 merupakan kurikulum yang bagus dan ideal, peserta didik lebih aktif dan mandiri dalam belajar. Namun, dalam implementasi masih membutuhkan penyempurnaan dan waktu implementasi terkesan mendadak. Beberapa guru mengungkapkan lebih merasa nyaman dengan KTSP.

3. Implementasi Kurikulum 2013 masih mengalami banyak kendala. Kendala tersebut adalah keterbatasan waktu, keterbatasan sarana dan prasarana, penilaian, dan keaktifan peserta di dik dalam proses belajar mengajar.

4. Guru kelas XII mata pelajaran Bahasa Indonesia SMA Negeri 3 Klaten mengatasi kendala implementasi Kurikulum 2013 dengan upaya sebagai berikut: a) untuk mengatasi keterbatasan waktu guru memberikan tugas rumah, mengadakan penilaian secara kelompok dan menyelesaikan administrasi guru di rumah. b) untuk mengatasi kendala keterbatasan sarana dan prasarana guru menggunakan media yang tersedia dan berusaha me lengkapi sarana dan prasarana secara mandiri. c) untuk mengatasi kesulitan menerapkan penilaian dengan melihat kondisi penilaian yang memungkinkan segera dilaksanakan, melakukan penilaian di luar kelas, memberikan tugas kelompok 
jika tidak memungkinkan dilakukan penilaian individu. Kesulitan pembuatan rubrik penilaian dilakukan dengan berdiskusi dan membahas dalam forum MGMP. Diskusi tersebut menghasilkan rubrik penilaian yang dapat digunakan bersama oleh guru se-Kabupaten Klaten. d) untuk mengatasi peserta didik yang kurang aktif, guru memberikan motivasi dan rangsangan berupa pemberian pujian atau penambahan nilai bagi peserta didik aktif.

\section{Daftar Pustaka}

Bintari, Ni Luh Gede Riwan Putri, I Nyoman Sudiana, Ida Bagus Putrayasa. 2014. "Pembelajaran Bahasa Indonesia Ber dasarkan Pendekatan Saintifik (Problem Based Learning) Sesuai Kurikulum 2013 Di Kelas VII SMP Negeri 2 Amlapura”. E-Journal, Vol 3. Hlm 6-9.

David A. Walczak.2010. A Program for Introducing Information Literacy to Commercial Art and Design. StudentsCommunications in Information Literacy. Volume3(2) Hal 193-203

Departemen Pendidikan Nasional. 2005. Undang-undang Republik Indonesia Nomor 14 tahun 2005 tentang Guru dan Dosen . Jakarta: Departemen Pendidikan Nasional.

Iswardah. 2007. "Penerapan Penilaian Otentik Pada Pembelajaran Bahasa Indonesia (Studi Kasus di MTsN Malang 1". Skripsi S1. Malang: Universitas Negeri Malang.

Kementrian Pendidikan dan Kebudayaan. 2012. "Pengembangan Kurikulum 2013" disampaikan dalam sosialisasi Kurikulum 2013 di Jember pada 25 Agustus 2013.

Kurinasih, Imas dan Berlin Sani (B). 2014. Sukses Mengimplementasikan Kurikulum 2013: Memahami Berbagai Aspek Dalam Kurikulum 2013 . Surabaya: Kata Pena.

Maryam, Siti. 2013. "Penerapan Penilaian Otentik dalam Pembelajaran Bahasa Indonesia di SMP se-Kecamatan Wates”. Skripsi S1. Yogyakarta: Universitas Negeri Yogyakarta

Nafisah, Yuni. 2014. "Implementasi Kurikulum 2013 Pada Mata Pelajaran Pendidikan Agama Islam Dan Budi Pekerti Di Sekolah Menengah Atas Negeri 2 Wates”. Skripsi S1. Yogyakarta: Universitas Islam Negeri Sunan Kalijaga.

Necdet AYKAÇ .2007. Evaluation of Activities in Primary Education Programme with The Teachers' Views (Sample of Sinop Province).Journal of Kirsehir Education Faculty.vol $8(2)$ Hal 19-35

Oliva, Peter F. 1982.Developing the Curriculum. Boston Toronto: Little Brown and Company

Sagala, S. 2003. Konsep dan Makna Pembelajaran: Untuk Membantu Memecahkan Problematika Belajar dan Mengajar. Bandung: Alfabeta. 